\title{
Vaginismus treatment with libido increase and practice
}

\author{
Pınar Yalçın Bahat*, Berna Aslan Çetin, Gökçe Turan
}

\begin{abstract}
Department of Obstetrics and Gynecology, Istanbul Kanuni Sultan Suleyman Training and Research Hospital, Istanbul, Turkey
\end{abstract}

Received: 03 May 2017

Accepted: 29 May 2017

\section{*Correspondence:}

Dr. Pınar Yalçın Bahat,

E-mail: dr_pinaryalcin@hotmail.com

Copyright: (c) the author(s), publisher and licensee Medip Academy. This is an open-access article distributed under the terms of the Creative Commons Attribution Non-Commercial License, which permits unrestricted non-commercial use, distribution, and reproduction in any medium, provided the original work is properly cited.

\begin{abstract}
Vaginismus is an involuntary contraction of the vaginal muscles which makes sexual intercourse difficult or impossible. It is one of the more common female psychosexual problems. The cases illustrate that it is important to rule out the possibility of vaginismus among patients with infertility. The aim of the report was to share with readers the cases with common presentations and underlying psychological causes.
\end{abstract}

Keywords: Libido, Pregnancy, Vaginismus

\section{INTRODUCTION}

Vaginismus and dyspareunia are classified under sexual pain disorders. They are closely interrelated and commonly overlooked in clinical practice. ${ }^{1}$ Pain may be experienced at vaginal entry, (superficial dyspareunia) or deep in the pelvis (deep dyspareunia). It is characterized by the over tightening of vaginal muscles causing strong, involuntary muscle spasms or intense pain during intercourse.

The etiology of sexual pain disorders is multi factorial. ${ }^{2}$ The etiology of vaginismus specifically may be due to trauma or surgery; the latter could be from childbirth, endometriosis and chronic urinary tract infections. Psychological triggers such as anxiety, stress, or past emotional or sexual abuse also play a part. Apart from physical causes, vaginismus also has strong psychological etiology. Fear, anxiety, partner distrust, negativity towards sex and traumatic childhood experiences are among the nonphysical components. Dyspareunia and vaginismus can lead to sexual impairment, emotional disturbances and marital disharmony. ${ }^{3}$
The aim of the report is to share with readers the cases with common presentations and underlying psychological causes. ${ }^{4}$

\section{CASE REPORT}

A 19-year old woman and her 22-year old husband came to the clinic because of failure to have sexual intercourse since their marriage 8 months ago. She feared sexual intercourse, the physical examination was normal except marked spasm of pelvic floor. An optimal pelvic examination could not be performed because of this spasm. The diagnosis was primary vaginismus. Paroxetine, which is an antidepressant (SSRI), was started for the treatment due to its non-decreasing property of sexual desire. In addition, $\mathrm{E}$ vitamin and lubricant gel was started. the treating physician explained the condition to the couple and gave them some basic guidance like Kegel exercises. At the end of 2 months, the couple were in sexual intercourse. 3 months later the woman conceived and gave birth without problems or complications after 39 weeks of pregnancy. approximately 2 months after giving birth the couple resumed normal sexual relations without any particular problems and without needing any treatment 


\section{DISCUSSION}

Vaginismus is defined as a persistent tightening of the vulva due to involuntary, painful, spasmodic contraction of the vulvovaginal canal preventing normal coitus or insertion of any object despite the woman's wish to do so. ${ }^{5}$ It has been further described as a recurrent or. persistent involuntary spasm of the musculature of the outer third of the vagina which interferes with intercourse. It is obvious that the vaginismus and dyspareunia have strong relationship (Figure 1). ${ }^{1}$

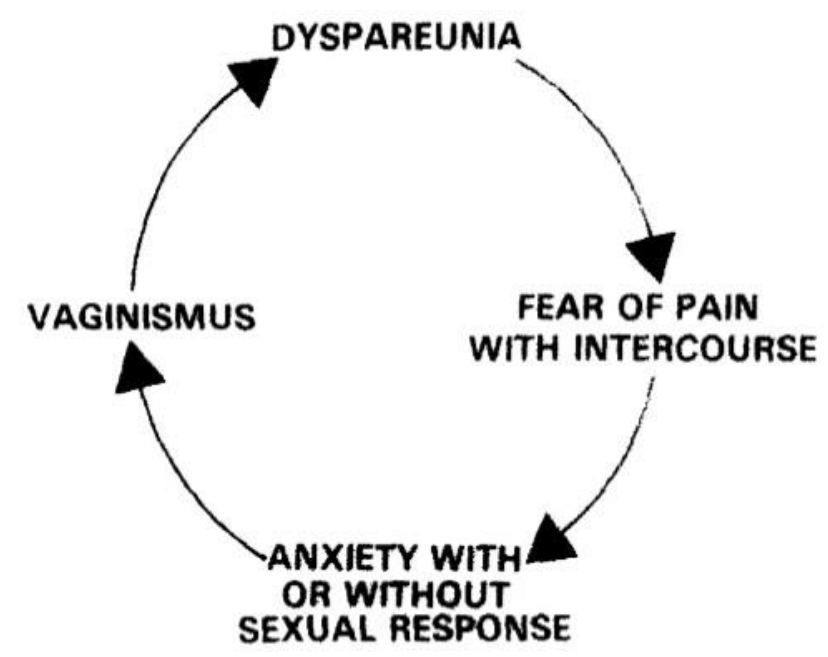

Figure 1: Dyspareunia and vaginismus cycle.

Much discussion exists in the literature about the etiology of dyspareunia, which is a symptom rather than a diagnosis. For the purposes of this discussion, the most common causes of dyspareunia that are likely to be encountered by the primary care practitioner are presented in Table $1 .^{6}$

There is a wide range of modalities that can be used to treat women with vaginismus. It ranges from psychological and behavioral intervention, the use of medicines and minor surgery. ${ }^{7}$

Pharmacological approach such as the use of local anesthetics (lidocaine), muscle relaxants (nitroglycerin ointment and botulinum toxin) and anxiolytic medication has been touted for its efficacies.

Surgical intervention is indicated only in patients with unusually thick hymen. ${ }^{8}$ Otherwise, surgical approach is not proven to be effective. Dilatation alone appeared to result in favorable outcomes. ${ }^{9}$

Traditionally, progressive vaginal dilatation for desensitization, sexual education, psycho-sexual therapy to reduce fear, negative conditioning and phobia, hypnotherapy, and biofeedback generally produced good outcome. $^{10}$
Table 1: Common causes of dyspareunia.

\begin{tabular}{|c|c|}
\hline S.N. & Causes of dyspareunia \\
\hline 1. & $\begin{array}{l}\text { Childbirth (cervical, uterine, and ligament } \\
\text { damage; episiotomyherve damage) }\end{array}$ \\
\hline 2 & Hymenal strandshnperforate hymen \\
\hline 3 & Coarse pubic hair \\
\hline 4 & Small introitus \\
\hline 5 & Endometriosis (cyclical pain) \\
\hline 6 & Diabetes (fragile mucosa) \\
\hline 7 & Hypoestrogenism (menopausal) \\
\hline 8 & Vaginismus \\
\hline 9 & $\begin{array}{l}\text { Chronic gastrointestinal disorders } \\
\text { (inflammatory and ulcerative) }\end{array}$ \\
\hline 10 & Fibroids (deep pelvic pain) \\
\hline 11 & $\begin{array}{l}\text { Urinary tract infection (often follows } \\
\text { intercourse) }\end{array}$ \\
\hline 12 & $\begin{array}{l}\text { Vulvodynia (chronic vulvar discomfort usually } \\
\text { classified as one of the following subsets: } \\
\text { infectious-candida, human papillomavirus, } \\
\text { herpes simplex virus; dermatoses- lichen } \\
\text { sclerosis and inflammatory dermatoses; vulvar } \\
\text { vestibulitis; iatrogenic causes; dysesthesia- } \\
\text { pudendal neuralgia and reflex sympathetic } \\
\text { dystrophy) }\end{array}$ \\
\hline
\end{tabular}

Funding: No funding sources

Conflict of interest: None declared

Ethical approval: Not required

\section{REFERENCES}

1. Diagnostic and statistical manual of mental disorders. 4th ed. Washington, DC: American Psychiatric Association; 1994.

2. Frank E, Anderson C, Kupfer DJ. Profiles of couples seeking sex therapy and marital therapy. Am J Psychiatry. 1976;133:559-62.

3. Crowley T, Richardson D, Goldmeier D. BASHH Special Interest Group for Sexual Dysfunction. Recommendations for the management of vaginismus: BASHH special interest group for sexual dysfunction. Int J STD AIDS. 2006;17:14-8.

4. Lew-Starowicz Z. Results of treatment of women with diagnosed vaginismus. Ginekologia Polska. 1982;33:691-4.

5. Reissing ED, Binik YM, Khalifé S. Does Vaginismus Exist? A Critical Review of the Literature. J Nerv Ment Dis. 1999;187:261-74.

6. Jones, Kim Dupree, Sally Tyler Lehr, and Sandra W. Hewell. Dyspareunia: Three case reports. J Obstet, Gynecol, and Neonat Nurs. 1997;19-23.

7. Hawton K. Sex therapy: A practical guide. Oxford: Oxford University Press; 1985.

8. Basson R, Leiblum S, Brotto L, Derogatis L, Fourcroy J, Fugl-Meyer K, et al. Definitions of women's sexual dysfunction reconsidered: Advocating expansion and revision. J Psychosom Obstet Gynaecol. 2003;24:221-9. 
9. McGuire $\mathrm{H}$, Hawton $\mathrm{K}$. Interventions for vaginismus. Cochrane Database Syst Rev. 2003;1:CD001760.

10. Graziottin A. Sexual pain disorders: Dyspareunia and vaginismus. In: Porst $\mathrm{H}$, Buvat J, editors. ISSM (International Society of Sexual Medicine) Standard committee book, standard practice in sexual medicine. Oxford, UK: Blackwell; 2006:342-50.

Cite this article as: Bahat PY, Çetin BA, Turan G. Vaginismus treatment with libido increase and practice. Int J Reprod Contracept Obstet Gynecol 2017;6:3167-9. 